\title{
Role of hyaluronic acid in joint lubrication
}

\author{
DAVID A. SWANN, * ERIC L. RADIN, $\dagger$ MICHAEL NAZIMIEC,* \\ PAUL A. WEISSER, $\dagger$ NANCY CURRAN, ${ }^{*}$ AND GEORGE LEWINNEK $\dagger$ \\ From the Departments of Biological Chemistry and Orthopedics, Harvard Medical School at the Shriners Burn \\ Institute* and Children's Hospital Medical Center, $\dagger$ Boston, Mass.
}

Hyaluronic acid is the macromolecule which endows synovial fluid with its viscoelastic properties and it is often assumed these properties are important for the lubrication of the tissue surfaces in diarthrodial joints (Barnett, Davies, and MacConaill, 1961). The relationships, if any, that exist between the chemical and physical properties of synovial fluid and its lubricating ability, however, have not been determined.

Recent in vitro studies concerned with the types of molecules present in synovial fluid which are responsible for the lubrication of the joint tissues have indicated that hyaluronic acid is a good lubricant for the synovial membrane (Radin, Paul, Swann, and Schottstaedt, 1971), but showed that this constituent was not essential for the lubrication of the articular cartilage (Radin, Swann, and Weisser, 1970). After the fractionation of synovial fluid by sedimentation equilibrium centrifugation in a cesium chloride density gradient, it was shown that the articular cartilage lubricating moiety was present in the protein fraction. More recent experiments have confirmed these data and shown that the lubricating moiety is complex and contains peptide and glycopeptide constituents (Swann and Radin, 1972). It thus appears from these in vitro studies that the different types of macromolecular constituents in synovial fluid can function independently in the lubrication of the different types of tissues in the joint. However, these constituents in vivo are intimately associated and the articular lubricating moiety interacts with hyaluronic acid and is retained as a component of the ultrafiltrate residue after the ultrafiltration of the synovial fluid (Swann and Radin, 1972). For this reason it is important to find out if hyaluronic acid has any effect on the lubricating ability of the protein fraction in an articular cartilage system.

A well known fact is that the concentration and intrinsic viscosity of hyaluronic acid are both lower in synovial fluid from patients with rheumatoid arthritis (Balazs, Watson, Duff, and Roseman, 1967), but it is not clear whether these changes modify the lubricating properties of the fluid. A characteristic feature of rheumatoid disease is morning stiffness, and a suggestion was made recently that this is caused by a failure in periarticular soft tissue lubrication
(Radin and others, 1971). It is also important, therefore, to determine whether the changes in the structure of hyaluronic acid and the composition of synovial fluid in patients with rheumatoid arthritis alters its ability to lubricate synovial tissue. The present experiments were performed in an attempt to answer some of these questions.

\section{Methods}

I PREPARATION OF SAMPLES FOR

LUBRICATION TESTING IN SYNOVIAL MEMBRANE SYSTEM

\section{(a) Human synovial fluid}

This was obtained from patients with classical rheumatoid arthritis by the A.R.A. classification (Hollander and McCarty, 1972) during joint arthroplasty operations. The fluids were put on ice immediately and clarified by centrifugation $90,000 \times g$ for 30 minutes at $4{ }^{\circ} \mathrm{C}$. Aliquots were then taken for analysis and the fluids were used directly to test their lubricating ability.

\section{(b) Hyaluronic acid samples}

The preparations used were obtained from a number of different tissues. Preparation A was prepared from the central and posterior peripheral regions of the cow vitreous (Swann and Constable, 1972). After centrifugation at $90,000 \times g$ for 60 minutes at $4^{\circ} \mathrm{C}$, the hyaluronic acid was precipitated with ethanol and the majority of the associated proteins were denatured by treatment with chloroform and removed by ultracentrifugation at $90,000 \times g$ for 60 minutes at $4^{\circ} \mathrm{C}$. Preparations B, C, D, and E were kindly supplied by Med-Chem Products Inc., Boston, Mass. These samples were obtained from rooster combs by water extraction and were treated with chloroform, repeated precipitation with ethanol and cetylpyridinium chloride (CPC), and ultracentrifugation to remove denatured proteins (Swann, 1968a). Preparations F and G were obtained from the dissected mucoid layer of rooster combs as described earlier (Swann, 1969a) with the exception that the pronase digestion step was omitted for sample G. Preparations $\mathrm{H}$ and I were obtained from bovine synovial fluid by sedimentation equilibrium centrifugation in a cesium chloride gradient and digestion with trypsin, respectively, as described below. Solutions containing these preparations were dialysed against $0.15 \mathrm{~mol} / \mathrm{l}$. veronal buffer, $\mathrm{pH} 7.2$ at $4^{\circ} \mathrm{C}$ before lubrication testing. 
II PREPARATION OF SAMPLES FOR

\section{LUBRICATION TESTING IN THE CARTILAGE} ON CARTILAGE SYSTEM

(a) Bovine synovial fluid not visibly contaminated with blood was obtained from the hind foot joints of adult cattle immediately after slaughter. The fluid from different joints was pooled, transported to the laboratory on ice, and clarified by centrifugation at $90,000 \times g$ for 30 minutes at $4^{\circ} \mathrm{C}$. The supernatant obtained was used to standardize the lubrication test systems in vitro and served as a starting material for the preparation of the other synovial fluid fractions.

(b) Ultrafiltration residue (UFR) is the fraction retained when clarified bovine synovial fluid is filtered through a $0.22 \mu \mathrm{m}$ millipore filter $16 \mathrm{~cm}$ in diameter at $4^{\circ} \mathrm{C}$ using vacuum to assist filtration. For lubrication test the UFR was resuspended in $0.15 \mathrm{~mol} / 1$. sodium chloride so that the final volume was equal to the volume of clarified synovial fluid from which the UFR was obtained.

\section{(c) Bovine synovial fluid protein fraction}

Clarified synovial fluid was adjusted to a density of $1.65 \mathrm{~g}$ / $\mathrm{ml}$ by the addition of cesium chloride and centrifuged at $220,000 \times g$ for $64 \mathrm{hrs}$ at $4^{\circ} \mathrm{C}$ (Radin, and others, 1970). After centrifugation the base of the tube was pierced and fractions were collected in sequence. The density, hexuronic acid, and protein content of each fraction were determined and the protein fraction, free of hyaluronic acid, was dialysed against four changes of $0.15 \mathrm{~mol} / \mathrm{l}$. veronal buffer $\mathrm{pH} 7 \cdot 2$ at $4 \mathrm{C}^{\circ}$.

\section{(d) Bovine synovial fluid hyaluronic acid}

(1) Fractions sedimenting at densities between 1.60 and $1.66 \mathrm{~g} / \mathrm{ml}$ after centrifugation for $64 \mathrm{hrs}$ at $220,000 \times \mathrm{g}$ at $4^{\circ} \mathrm{C}$ in a cesium chloride gradient (Radin and others, 1970) were dialysed against distilled water immediately after collection of the samples, then against $1 \mathrm{~mol} / \mathrm{l}$. sodium chloride at $4^{\circ} \mathrm{C}$ and finally against two changes of $0.15 \mathrm{~mol} / \mathrm{l}$.veronal buffer $\mathrm{pH} 7.2$ at $4^{\circ} \mathrm{C}$ (preparation $\mathrm{H}$, Table I).

(2) Clarified synovial fluid adjusted to $\mathrm{pH} 7 \cdot 2$ with Tris buffer (final concentration $0.05 \mathrm{~mol} / \mathrm{l}$. Tris- $\mathrm{HCl}, 0.001$ mol/l. calcium chloride) was digested with trypsin (Worthington, TRL 100S, $27 \mathrm{mg} / 250 \mathrm{ml}$ synovial fluid) for $24 \mathrm{hrs}$ at $37^{\circ} \mathrm{C}$ to destroy lubricating ability in the articular cartilage test system. The hyaluronic acid was then precipitated by addition of ethanol ( $3 \mathrm{vol})$, dissolved in $0.15 \mathrm{~mol} / 1$. sodium chloride, treated with chloroform, reprecipitated with ethanol, again dissolved with $0 \cdot 15 \mathrm{~mol} / 1$. sodium chloride, and dialysed against $0 \cdot 15 \mathrm{~mol} / \mathrm{l}$. veronal buffer $\mathrm{pH} 7 \cdot 2$ at $4^{\circ} \mathrm{C}$. The hyaluronic acid was clarified by centrifugation at $90,000 \times g$ for 30 minutes at $4^{\circ}$ (preparation I, Table I). Before lubrication testing excess soybean antitrypsin (Worthington, SI, $1 \mathrm{mg} / \mathrm{ml}$ ) was added both to the test sample and protein fraction, and no residual tryptic activity could be detected after the addition of this inhibitor.

\section{SYNOVIAL MEMBRANE LUBRICATION} ASSAY

This procedure was carried out by moving a glass plate wetted with the test sample beneath a piece of synovial membrane loaded with a $200 \mathrm{~g}$ weight. The drag on the synovial membrane was measured using a force transducer and was recorded on a strip chart. Three such measurements were made for each test sample and the coefficient of friction was calculated by dividing the average frictional force recorded by the load (Radin and others, 1971).

\section{ARTICULAR CARTILAGE LUBRICATION ASSAY}

The lubrication tests were carried out using bovine metatarsal-phalangeal joints oscillated in a bath of the test

Table I Composition and properties of hyaluronic acid preparations and synovial fluid fractions*

\begin{tabular}{|c|c|c|c|c|c|c|}
\hline \multirow[b]{2}{*}{ Sample } & \multicolumn{2}{|c|}{ Protein content $^{*}$} & \multirow{2}{*}{$\begin{array}{l}\text { Hexuronic* } \\
\text { acid }\end{array}$} & \multirow{2}{*}{$\begin{array}{l}\text { Intrinsic } \dagger \\
\text { viscosity }\end{array}$} & \multicolumn{2}{|c|}{ Lubricating ability $y_{+}^{+}$} \\
\hline & Lon'ry & Amino acids & & & Soft tissue & Articular cartilage \\
\hline \multicolumn{7}{|l|}{ Hyaluronic acids } \\
\hline $\begin{array}{l}A \\
B\end{array}$ & $9 \cdot 7$ & & 31 & 920 & & \\
\hline $\begin{array}{l}\mathrm{B} \\
\mathrm{C}\end{array}$ & $\begin{array}{l}0.36 \\
0.35\end{array}$ & 0.5 & $\begin{array}{l}51 \\
48\end{array}$ & $\begin{array}{l}1850 \\
2000\end{array}$ & & \\
\hline D & $0 \cdot 11$ & & 42 & 3400 & & \\
\hline $\mathrm{E}$ & 1.92 & & 39 & 4000 & & \\
\hline $\mathrm{F}$ & $1 \cdot 27$ & & 31 & 6000 & & \\
\hline G & & $14 \cdot 2$ & 30 & 9200 & & \\
\hline $\mathbf{H}$ & & $2 \cdot 3$ & 29 & 8600 & & 0 \\
\hline I & & $16 \cdot 9$ & 33 & 8000 & & 0 \\
\hline \multicolumn{7}{|l|}{ Synovial fluid fractions } \\
\hline Synovial fluid & $1 \cdot 27 \S$ & & $0.49 \S$ & 9500 & 100 & 100 \\
\hline Ultrafiltrate residue & $0 \cdot 30 \S$ & & $0.45 \S$ & 5500 & $90-107$ & 106 \\
\hline Ultrafiltrate filtrate & $0.92 \S$ & & $0.02 \S$ & & 0 & 0 \\
\hline Protein fraction & & 98 & 0.5 & & 0 & 105 \\
\hline
\end{tabular}

* Data expressed as $w / w \%$ of lyophilized sample.

+ Intrinsic viscosity in $\mathrm{ml} / \mathrm{g}$.

廿ubricating ability expressed as \% bovine synovial fluid.

$\S$ Data expressed as $\mathrm{mg} / \mathrm{ml}$ fluid sample. 
lubricant at $40 \mathrm{cpm}$ under load of $226 \mathrm{~kg}$ as previously described (Linn, 1967, 1968). The coefficients of friction obtained with test samples were compared with the values for fresh synovial fluid and buffer which were run as controls in the same test series.

\section{ANALYTICAL DETERMINATIONS}

Protein was determined using the Folin-Phenol method of Lowry, Rosebrough, Farr, and Randall (1951) and by amino acid analysis after hydrolysis with $6 \mathrm{~N}$ hydrochloric acid for 24 hours at $105^{\circ} \mathrm{C}$ in sealed tubes (Swann, 1968b). Hexuronic acid analyses were carried out using a manual carbazole reaction in the presence of borate (Balazs, Berntsen, Karossa, and Swann, 1965). Hyaluronic acid concentrations were obtained by multiplying the hexuronic acid concentrations by a factor of 1.95. Hexosamines were determined using a manual p-dimethylaminobenzaldehyde reaction (Swann and Balazs, 1966) and also by ion-exchange chromatography on an amino acid analyser using a $15 \mathrm{~cm} \times 0.9 \mathrm{~cm}$ column packed with phoenix spherix XX8 resin. Intrinsic viscosity measurements were performed at $37^{\circ} \mathrm{C}$ in a Cannon-Ubbelohde semimicre dilution viscometer* after dialysis against $0.15 \mathrm{~mol} / \mathrm{l}$. sodium chloride $\mathrm{pH} 7 \cdot 2$ at $4^{\circ} \mathrm{C}$. Intrinsic viscosity values of the hyaluronic acid samples were determined by extrapolating the reduced viscosities to zero concentration. Relative viscosity measurements were performed at $37^{\circ} \mathrm{C}$ on $1 \mathrm{ml}$ of clarified synovial fluid in a semimicro viscometer with a flow time of 109 seconds. Infrared spectra of the hyaluronic acid preparations were determined on thin films of the sodium salts with a Perkin Elmer model 237 infrared spectrophotometer.

\section{Results}

The major difficulty associated with the measurement of the lubricating ability of test samples was the variability from test series to test series because different pieces of synovium and different joints were used. In order to obtain comparable data, therefore, all coefficient of friction measurements were related to the values obtained with $0.15 \mathrm{~mol} / \mathrm{l}$. veronal buffer $\mathrm{pH} 7.2$ and with fresh synovial fluid. The lubricating advantage of samples was then calculated using the formula similar to those previously reported (Swann, 1968a). Preparation A contained about $10 \%$ protein and preparations $\mathrm{C}, \mathrm{D}$, and $\mathrm{E}$ contained less than $0.5 \%$. Preparation $\mathrm{G}$ contained $14.2 \%$ as protein. The amino acid composition of some of these samples used in the lubrication tests are shown in Table II. The lowest viscosity value was obtained with hyaluronic acid from the cow vitreous, which is to be expected from the earlier studies (Varga, 1955). Preparations B, C, D, and $E$ were all purified by similar methods, namely, denaturation of proteins by treatment with chloroform, repeated precipitation with CPC and ethanol followed by ultracentrifugation (Swann, 1968a). The highest viscosity value was obtained with preparation $\mathrm{G}$ from the mucoid layer of rooster combs. Preparation $\mathrm{H}$ obtained by fractionation of bovine synovial fluid by cesium chloride density gradient centrifugation also had a high viscosity value $(8600 \mathrm{ml} / \mathrm{g})$, but the amino acid content was only $2.3 \%$. The intrinsic viscosity measurements were performed after dialysis against $0 \cdot 15 \mathrm{~mol} / 1$. sodium chloride on samples which had not previously been subjected to lyophilization. The viscosity values were calculated after extrapolation to zero concentration as shown in Fig. 3. The chemical analyses were carried out on aliquots of the lyophilized and air dry material after extensive dialyses of the samples against distilled water to remove salts. The sodium and moisture contents were not determined. As shown in Fig. 1 the lubricating ability of hyaluronic acid depended on both the intrinsic viscosity of the sample and also its concentration in solution. All of the lubricating ability of synovial fluid was present in the ultrafiltrate residue fraction.

HUMAN RHEUMATOID SYNOVIAL FLUIDS

A total of 14 rheumatoid fluids were obtained in sufficient quantity for analysis and lubrication testing in the soft tissue system. The analytical data are shown in Table III. The hyaluronic acid concentration varied from 0.8 to $1.7 \mathrm{mg} / \mathrm{ml}$, with a mean value of $1.24 \mathrm{mg} / \mathrm{ml}$. There was also more than a twofold

$$
\frac{\text { Coefficient of friction (buffer) - coefficient of friction (sample) } \times 100}{\text { Coefficient of friction (buffer) }}=\text { Lubricating advantage }
$$

This value for the sample was then calculated as a percentage of the lubricating advantage obtained with the fresh synovial fluid used in the same test series to obtain a relative estimate of the sample's lubricating ability.

\section{SOFT TISSUE LUBRICATION TESTS}

The chemical compositions of the various hyaluronic acid preparations are shown in Table I, and their lubricating abilities in Fig. 1. The infrared spectra (Fig. 2) are typical of sodium hyaluronate and are

* Cannon Instrument Co., State College, Pa., U.S.A. variation in the concentration of protein. The range was 2.53 to $5.66 \% \mathrm{w} / \mathrm{v}$ and the mean value was $4.52 \% \mathrm{w} / \mathrm{v}$. All of the rheumatoid synovial fluids tested had lubricating abilities similar to bovine synovial fluid using the synovium membrane assay system.

\section{ARTICULAR CARTILAGE LUBRICATION}

The chemical analysis of the various bovine synovial fluid fractions tested for their lubricating ability in the articular cartilage system are shown in Table I. The ultrafiltration residue obtained after one filtration was composed of approximately $24 \%$ protein. 
The protein fraction obtained after cesium chloride density gradient centrifugation contained negligible amounts of glucuronic acid and was composed of $\mathbf{9 8} \%$ protein by amino acid analysis. The hyaluronic acid preparation obtained by tryptic digestion contained $\mathbf{1 6 . 9} \%$ protein by amino acid analysis compared to only $2 \cdot 3 \%$ after purification by density gradient fractionation and neither of the preparations possessed any lubricating ability in the articular cartilage system. Both the ultrafiltrate residue fraction and the protein fraction from synovial fluid possessed lubricating ability equivalent to that observed with whole synovial fluid.

When the lubricating ability of the synovial fluid protein fraction was tested continuously over a period of $15 \mathrm{hrs}$ it was observed that the lubricating

Table II Amino acid composition of hyaluronic acid samples, residues/1,000 residues

\begin{tabular}{|c|c|c|c|c|}
\hline & $\begin{array}{l}\text { Ultrafiltration } \\
\text { residue }\end{array}$ & $\begin{array}{l}\text { Hyaluronic* } \\
\text { acid C }\end{array}$ & $\begin{array}{l}\text { Hyaluronic } \\
\text { acid } G\end{array}$ & $\begin{array}{l}\text { Hyaluronic } \\
\text { acid } H\end{array}$ \\
\hline Lysine & 69 & 46 & 73 & 68 \\
\hline Histidine & 22 & 33 & 34 & 15 \\
\hline Arginine & 37 & 21 & 55 & 16 \\
\hline Aspartic acid & 86 & 84 & 109 & 96 \\
\hline Threonine & 80 & 51 & 56 & 79 \\
\hline Serine & 105 & 186 & 62 & 148 \\
\hline Glutamic acid & 110 & 106 & 109 & 201 \\
\hline $\begin{array}{l}\text { Proline } \\
\text { Pall }\end{array}$ & 60 & 37 & 42 & 25 \\
\hline Glycine & 68 & 178 & 79 & 105 \\
\hline Alanine & 63 & 89 & 75 & 75 \\
\hline Cystine/2 & 28 & - & 21 & 20 \\
\hline Valine & 91 & 54 & 63 & 15 \\
\hline Methionine & 7 & - & 17 & 6 \\
\hline Isoleucine & 25 & $\overline{32}$ & 41 & 32 \\
\hline Leucine & 80 & 48 & 87 & 51 \\
\hline Tyrosine & 36 & 16 & 34 & 20 \\
\hline Phenylalanine & 35 & 19 & 46 & 31 \\
\hline
\end{tabular}

* Swann (1968b).

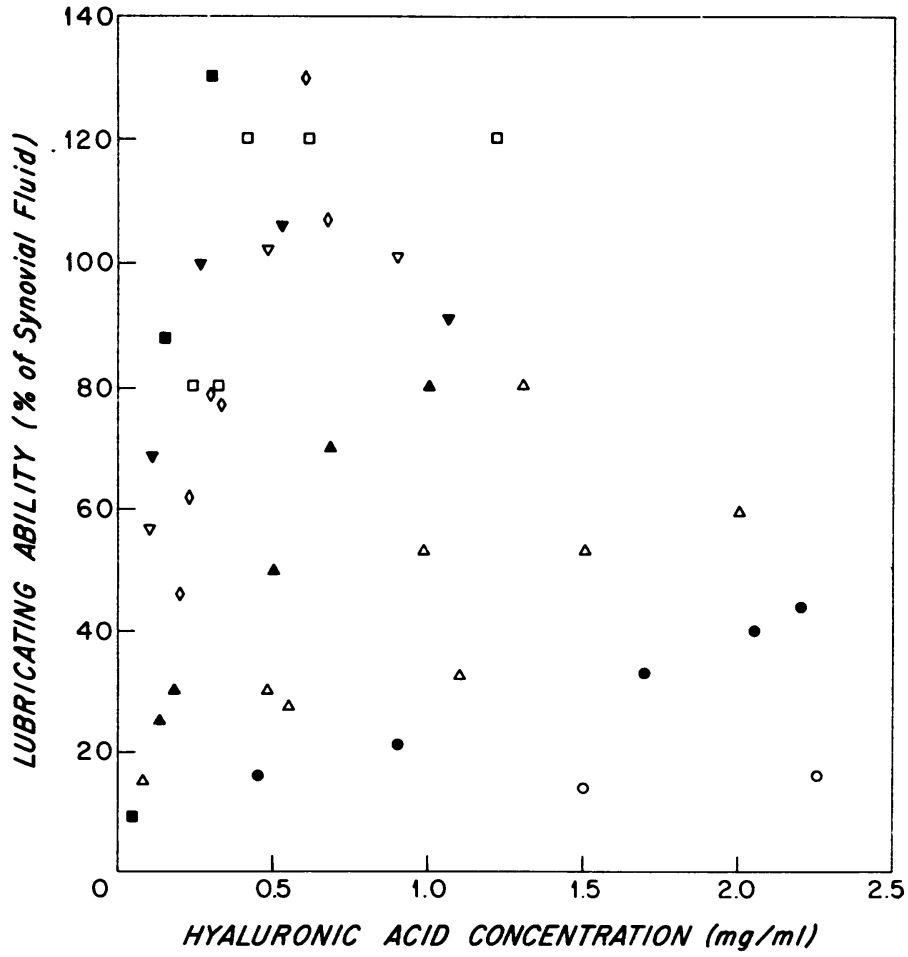

FIG. 1 Lubricating ability of hyaluronic acid preparations (Table I). Data obtained with preparation $A-0, B-0, C-\Delta$, $D-\Delta, E-\square, F-\square, G-\diamond, H-\nabla$; ultrafiltrate residue data $\nabla$ 


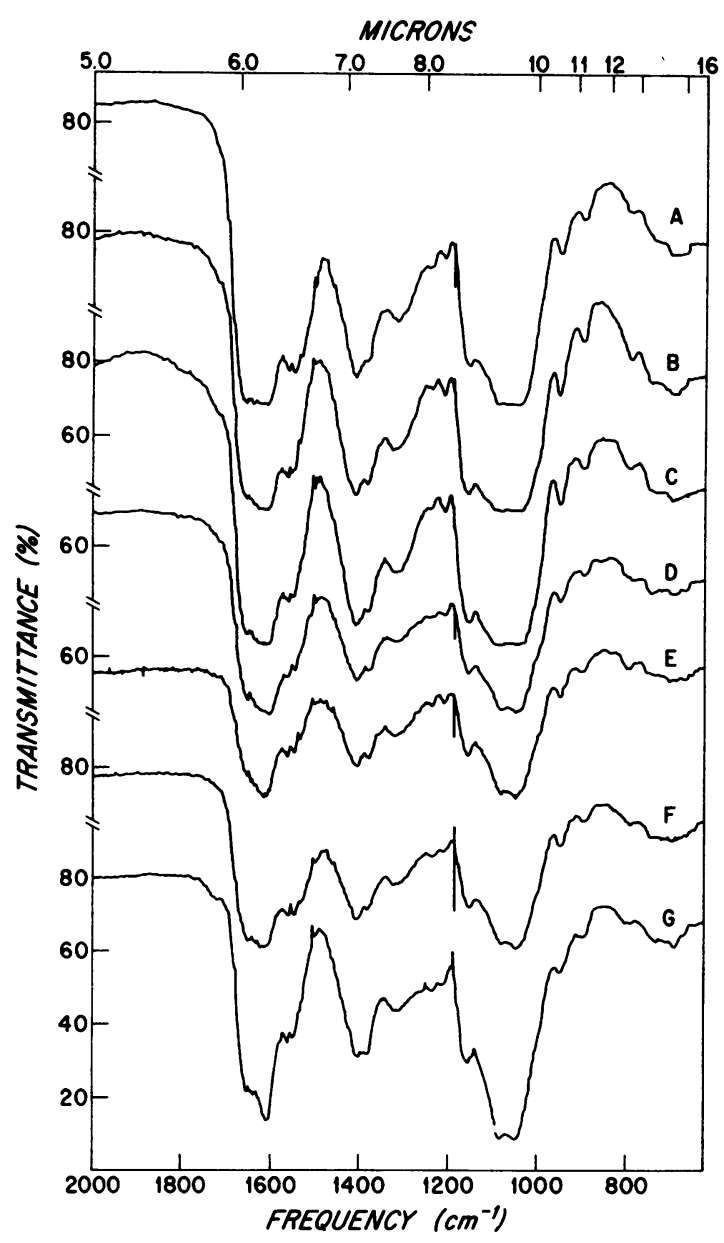

FIG. 2 Infrared spectra of hyaluronic acid preparation (Table I). Curve $A$ - preparation $A$; curve $B$-preparation $B$; curve $C$ - preparation $D$; curve $D$ - preparation $E$; curve $E$ - preparation $F$; curve $F$ - preparation $G$; and curve $G$ - preparation $H$

ability persisted for varying lengths of time depending on the joint used in the assay system and also the methods used to prepare the test sample. The effect of mixing hyaluronic acid with the synovial fluid protein fraction on the lubricating ability of the latter sample was therefore tested in two similar joint systems (determined by measurements with veronal buffer and synovial fluid) run simultaneously with fractions obtained from the same batch of synovial fluid. The results of longevity tests performed with the whole synovial fluid, ultrafiltrate residue, the protein and the hyaluronic acid fractions from synovial fluid are shown in Table IV. The errors associated with these measurements of lubricating ability in the articular cartilage system was $\pm 5 \%$ and those samples which initially possessed similar lubricating ability to synovial fluid within experimental

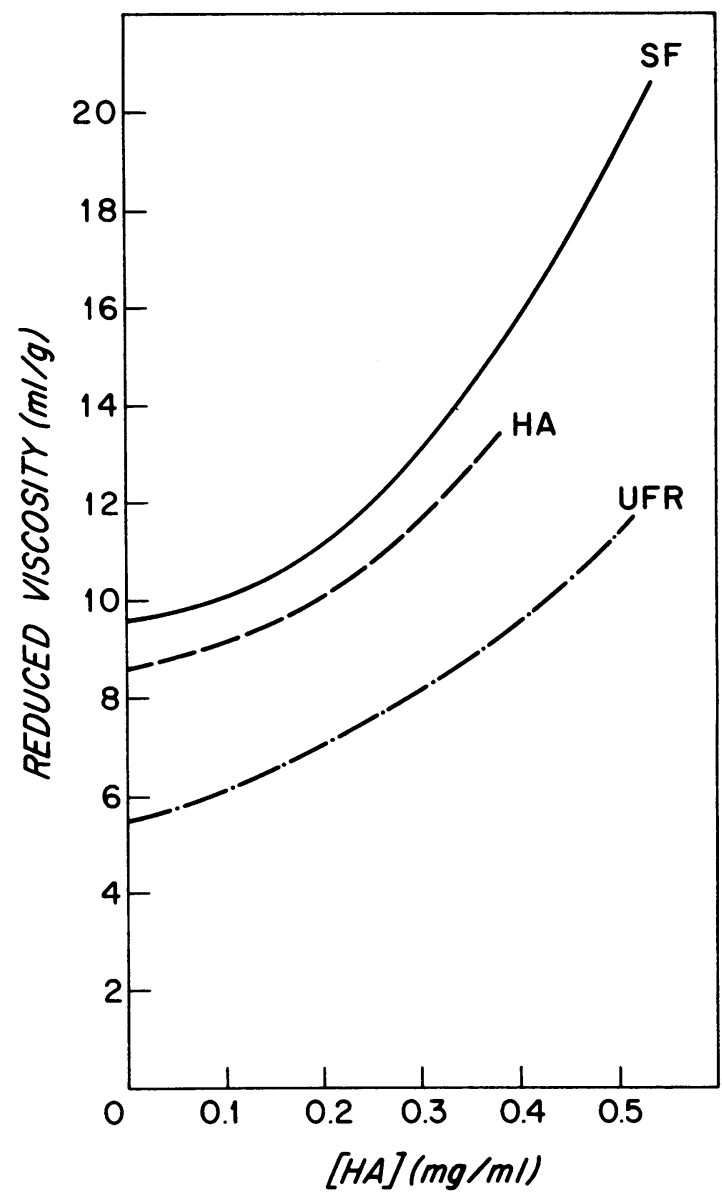

FIG. 3 Relationship between the reduced viscosity measurements and hyaluronic acid concentration for bovine synovial fluid $(S F)$, ultrafiltrate residue (UFR), and hyaluronic acid prepared from bovine synovial fluid by cesium chloride density gradient sedimentation $(H A)$. The intrinsic viscosity is the intercept value obtained by extrapolating the curve to zero concentration

error were given a value of $100 \%$ lubricating ability Subsequent values in the longevity tests with these samples were then related to this initial value.

\section{Discussion}

LUBRICATION OF SYNOVIAL MEMBRANE BY HYALURONIC ACID

Previous experiments showed that sodium hyaluronate from rooster combs and bovine synovial fluid were good lubricants for this tissue and that the lubricating ability of these materials was destroyed by treatment with hyaluronidase (Radin and others, 1971). It was not determined, however, in what way the lubricating ability of the hyaluronic acid was related to the degree of degradation. The present 
experiments were performed with hyaluronic acid preparations with different intrinsic viscosities to determine the extent to which this molecular parameter is related to its lubricating ability in the synovial membrane system. The data in Fig. 1 show that lubrication in this system is dependent on both concentration and on the intrinsic viscosities of the hyaluronic acid preparations. Considerable variations were observed with different concentrations of individual preparations, which was probably caused by the limitations of the test procedure, but with increasing concentrations of hyaluronic acid the lubricating ability also tended to improve. The lubricating ability was also clearly related to the intrinsic

Table III Analysis and lubricating properties of human rheumatoid synovial fluids

\begin{tabular}{|c|c|c|c|c|c|c|}
\hline Sample no. & $\begin{array}{l}\text { Intrinsic } \\
\text { viscosity } \\
(\mathrm{ml} / \mathrm{mg})\end{array}$ & $\begin{array}{l}\text { Relative } \\
\text { viscosity }\end{array}$ & $\begin{array}{l}\text { Hyaluronic } \\
\text { acid } \\
(\mathrm{mg} / \mathrm{ml})\end{array}$ & $\begin{array}{l}\text { Protein } \\
(\% w / v)\end{array}$ & $\begin{array}{l}\text { Absorbance } \\
\text { at } 1 / 100 \\
\text { dilution }\end{array}$ & $\begin{array}{l}\text { Lubricating } \\
\text { ability* } \\
(\%)\end{array}$ \\
\hline $\begin{array}{l}\text { D-1 } \\
\text { D-2 } \\
\text { D-3 } \\
\text { D-4 } \\
\text { D-5 } \\
\text { D-6 } \\
\text { D-7 } \\
\text { D-8 } \\
\text { D-9 } \\
\text { D-10 } \\
\text { D-11 } \\
\text { D-12 } \\
\text { D-13 } \\
\text { D-14 } \\
\text { Average }\end{array}$ & $\begin{array}{l}4700 \\
6500 \\
4000 \\
6300 \\
3750 \\
4000 \\
4600 \\
5600 \\
4050 \\
5900 \\
4200 \\
4870 \\
(3750-6500)\end{array}$ & $\begin{array}{r}24 \cdot 5 \\
16 \cdot 9 \\
6 \cdot 5 \\
20 \cdot 9 \\
\\
15 \cdot 2 \\
18 \cdot 8 \\
16 \cdot 6 \\
18 \cdot 8 \\
27 \cdot 5 \\
22 \cdot 2 \\
14 \cdot 7 \\
18 \cdot 7\end{array}$ & $\begin{array}{l}1 \cdot 14 \\
0.90 \\
0.80 \\
1.59 \\
1.67 \\
1.70 \\
1.10 \\
1.14 \\
1.43 \\
0.84 \\
1.06 \\
1.63 \\
1.18 \\
1.24 \\
(0.80-1 \cdot 70)\end{array}$ & $\begin{array}{l}4 \cdot 15 \\
4 \cdot 50 \\
5 \cdot 66 \\
2 \cdot 53 \\
4 \cdot 62 \\
4 \cdot 26 \\
\\
5 \cdot 60 \\
3 \cdot 98 \\
4 \cdot 39 \\
5 \cdot 21 \\
4 \cdot 85 \\
4 \cdot 52 \\
(2 \cdot 53-5 \cdot 66)\end{array}$ & $\begin{array}{l}0.471 \\
0.390 \\
0.572 \\
0.385 \\
0.277 \\
0.550 \\
0.487\end{array}$ & $\begin{array}{r}126 \\
95 \\
93 \\
87 \\
\overline{97} \\
97 \\
107 \\
88 \\
104 \\
81 \\
108 \\
80 \\
\overline{97}\end{array}$ \\
\hline
\end{tabular}

- Lubricating ability expressed as a percentage of bovine synovial fluid.

Table IV Variation of lubricating ability with time of bovine synovial fluid fractions in the articular cartilage system*

\begin{tabular}{|c|c|c|c|c|c|c|c|c|}
\hline \multirow[t]{2}{*}{ Test no. } & \multicolumn{2}{|l|}{$I$} & \multicolumn{2}{|l|}{ II } & \multicolumn{2}{|l|}{$I I I$} & \multicolumn{2}{|l|}{$I V$} \\
\hline & $\begin{array}{l}\text { Synovial } \\
\text { fluid }\end{array}$ & $\begin{array}{l}\text { Ultrafiltration } \\
\text { residue }\end{array}$ & $A$ & $\boldsymbol{B}$ & $A$ & $\boldsymbol{B}$ & $A$ & $\boldsymbol{B}$ \\
\hline \multicolumn{9}{|l|}{ Time (hrs) } \\
\hline 0.25 & 100 & 106 & 100 & 88 & 100 & 106 & 100 & 100 \\
\hline 0.5 & 100 & 25 & 100 & 23 & 94 & 94 & 87 & 100 \\
\hline 1.5 & 100 & 0 & 100 & 23 & 66 & 71 & 73 & 43 \\
\hline 2.5 & 84 & 0 & 100 & 23 & 50 & 60 & 38 & 21 \\
\hline $3 \cdot 5$ & 84 & -25 & 100 & 23 & 45 & 47 & 38 & 16 \\
\hline $4 \cdot 5$ & 84 & -25 & 100 & 12 & 45 & 47 & 24 & 16 \\
\hline $5 \cdot 5$ & 84 & -25 & 100 & 12 & 45 & 47 & 24 & 16 \\
\hline 6.5 & 84 & -25 & 100 & 0 & 45 & 47 & 24 & 16 \\
\hline $7 \cdot 5$ & 17 & -125 & 100 & 0 & 34 & 47 & 24 & 11 \\
\hline 8.5 & 17 & -150 & 100 & 0 & 34 & 47 & 11 & 11 \\
\hline 9.5 & -17 & -200 & 100 & 0 & 34 & 36 & 11 & 11 \\
\hline 10.5 & -17 & -238 & 100 & 0 & 34 & 36 & 5 & 11 \\
\hline $11 \cdot 5$ & -66 & -238 & 100 & 0 & 34 & 36 & 5 & 0 \\
\hline $12 \cdot 5$ & -66 & -238 & 100 & 0 & 21 & 24 & 0 & 0 \\
\hline $13 \cdot 5$ & -66 & -250 & 100 & 0 & 21 & 24 & 0 & 0 \\
\hline 14.5 & -66 & -250 & 80 & 0 & 21 & 13 & 0 & 0 \\
\hline 15.5 & -83 & -250 & 80 & 0 & 10 & 13 & 0 & 0 \\
\hline \multicolumn{9}{|c|}{ Composition of samples $(\mathrm{mg} / \mathrm{ml})$} \\
\hline Hyaluronic acid & 0.96 & 0.83 & 0 & 1.05 & 0 & 0.95 & 0 & $1 \cdot 10$ \\
\hline Protein & $1 \cdot 27$ & $0 \cdot 30$ & $1 \cdot 30$ & $1 \cdot 58$ & $1 \cdot 60$ & $1 \cdot 85$ & $1 \cdot 50$ & $1 \cdot 58$ \\
\hline
\end{tabular}

* The protein fraction obtained from bovine synovial fluid by cesium chloride density gradient sedimentation was mixed with buffer (A) and with hyaluronic acid (B).

In tests II and III the hyaluronic acid was obtained by digestion of synovial fluid with trypsin and in test IV by cesium chloride density gradient sedimentation.

The protein concentrations in the samples used in tests II and III were determined before the addition of soybean antitrypsin. 
viscosity of the samples. The samples with intrinsic viscosity values above $4,000 \mathrm{ml} / \mathrm{g}$ possessed similar lubricating abilities to bovine synovial fluid, whereas at most of the concentrations tested preparations A, B, C, D were inferior lubricants.

It is difficult to interpret these data exactly because the intrinsic viscosity value of hyaluronic acid is dependent upon many factors. Earlier experiments have shown that rooster comb hyaluronic acid contained weak linkages that were irreversibly cleaved by temperatures about $65^{\circ}$ (Swann, 1969a) and that at high pH the intrinsic viscosity was decreased, though the molecular weight remained constant (Swann, 1970). Silpananta, Dunstone, and Ogston (1968) also showed that the molecular weight of bovine ultrafiltrate residue hyaluronic acid was unaltered, whereas the intrinsic viscosity value decreased after fractionation of the polysaccharide and protein constituents. These studies indicate that the polysaccharide chains of hyaluronic acid can interact with adjacent molecules and can assume different conformations in solution. More recent studies using $x$-ray crystallography (Atkins and Sheehan, 1972, 1973; Dea, Moorhouse, Rees, Arnott, Guss, and Balazs, 1973) have confirmed and extended these earlier observations and shown that the hyaluronic acid polysaccharide chain can occur in the form of a helix as well as other conformations.

In a previous study it was shown that the molecules in solutions of highly purified preparations of hyaluronic acid had a random coil configuration (Laurent, Ryan, and Pietruszkiewicz, 1960), but the molecules in the connective tissue in vivo may have a different structure. In this case the decrease in the intrinsic viscosity of hyaluronic acid that occurs during purification (Swann, 1968a) may be a measure of a change in structure. Under these circumstances the superior lubricating ability of those hyaluronic acid preparations with high intrinsic viscosity values (Fig. 1) could be related to one or a number of the above factors, namely the length, conformation, and state of aggregation of the polysaccharide chains or the interaction of the chains with other protein molecules. Scher and Hamerman (1972) have obtained data which suggest that hyaluronic acid from human synovial fluid is present as a complex with protein and the hyaluronic acid preparation prepared from bovine synovial fluid by density gradient fractionation had a similar protein content to that found by these workers (preparation $\mathrm{H}$, Table I). The lubricating ability, however, did not seem to be related to the total protein component of the samples, which indicates that this function is dependent upon the structure and organization of the polysaccharide chains of hyaluronic acid. It is not known, however, in what way the small quantities of protein always found in hyaluronic acid (Swann, 1968b) contribute to the structure of this substance.
An additional factor is that purified hyaluronic acid occurs in solution as a polydisperse mixture of molecules (Laurent and others, 1960; Swann, 1969b). It is thus possible that samples with different intrinsic viscosity values may contain some molecules with a similar molecular weight and conformation. This fact may be responsible for some of the variations in the lubrication data with individual preparations and the finding that there was not a clear-cut difference between the lubricating abilities of samples with different intrinsic viscosities.

One interpretation of the lubrication data which is compatible with the above data is that hyaluronic acid is able to lubricate synovial tissue when it possesses a structure which is similar to that which occurs in vivo and that if this structure is degraded then the lubricating ability is decreased. Optimum lubrication would then be achieved when a sufficient number of undenatured molecules are present and when their function is not impeded by competition with other nonlubricating and denatured hyaluronic acid molecules.

LUBRICATION OF SYNOVIAL MEMBRANE BY HUMAN RHEUMATOID SYNOVIAL FLUID

Analysis of the rheumatoid synovial fluid showed that the concentration of protein was increased and that the concentration of hyaluronic acid was decreased. The ranges for these values were similar to those reported in the literature. The intrinsic viscosity of the hyaluronic acid in these synovial fluids was also somewhat lower than in normals, which again agreed with previous studies (Balazs and others, 1967). When the lubricating ability of these synovial fluids was tested in the synovial membrane system, however, it was observed that they possessed similar lubricating properties to whole bovine synovial fluid. Again, a spread of values was observed (80-126\% lubricating ability), but the average of all samples was $97 \%$. These data suggest that though there are certain changes both in concentration and intrinsic viscosity of the hyaluronic acid in rheumatoid synovial fluid, these changes are not sufficient to limit the ability of the fluid to lubricate the synovial membrane. This conclusion agrees with the data already presented for the various hyaluronic acid preparations. Only those preparations with an intrinsic viscosity of less than $4,000 \mathrm{ml} / \mathrm{g}$ or a concentration less than $0.5 \mathrm{mg} / \mathrm{ml}$ showed lowered lubricating ability when compared to whole bovine synovial fluid. The lowest hyaluronic acid concentration in rheumatoid synovial fluids was $0.8 \mathrm{mg} / \mathrm{ml}$ and the lowest viscosity was $3,750 \mathrm{ml} / \mathrm{g}$, and so it would be expected that all of these samples would lubricate synovial fluid in a similar manner to normal bovine synovial fluid.

LUBRICATION OF ARTICULAR CARTILAGE

The data shown in Tables I and IV support the earlier experiments where it was shown that the moiety 
responsible for articular lubrication was a protein constituent (Radin and others, 1970; Swann and Radin, 1972). All the lubricating ability was found to be present in the protein fraction and the ultrafiltrate residue in the short-term tests (Table I) and there was no difference between the lubricating abilities of these two samples. When the tests were continued for extended periods of time, however, the synovial fluid and ultrafiltrate residue lost their lubricating ability and eventually became inferior lubricants when compared to buffer alone. It is thought that this 'gumming up' effect may be caused by the accumulation of constituents on the articulating surface which inhibit the flow of water in and out of the cartilage and thus retard the hydrostatic component of the lubricating mechanism (Radin and Paul, 1972). Also as indicated in Table IV the types of results obtained in the longevity tests varied from test to test and also depended on the methods used to prepare test samples. Thus, with test II the protein/buffer fraction lubricated continuously for more than $13 \mathrm{hrs}$, whereas the same protein fraction when mixed with hyaluronic acid prepared from bovine synovial fluid by digestion with trypsin gave a lowered initial lubricating ability which decreased gradually with time. In other similar experiments (test III and IV) using different preparations of protein fraction and hyaluronic acids prepared by tryptic digestion (test III) and by density gradient sedimentation (test IV), the protein/buffer sample and the protein/hyaluronic acid sample had similar lubricating abilities in each test. Despite these variations, which may have been caused by a great number of factors, it appears that hyaluronic acid does not aid in the lubrication of articular cartilage in any way. The fact that the articular lubricant is closely associated with the hyaluronic acid in synovial fluid may not therefore be of functional significance.

An explanation for this finding may be that while the majority of the hyaluronic acid in joint fluid is produced by the synovial membrane (Blau, Janis, Hamerman, and Sandson, 1965), the articular lubricant or a component of this fraction together with small quantities of hyaluronic acid may be derived from the articular cartilage itself and may only occur in synovial fluid as a consequence of natural wear processes. Recent experiments in vitro have shown that hyaluronic acid can interact with cartilage proteoglycans to form aggregates (Hardingham and Muir, 1972; Gregory, 1973). Articular lubrication, therefore, may be an inherent property of the articular cartilage per se and the role of the synovial fluid would then be to interact with this surface, to act as a wash fluid, and to lubricate the adjacent soft tissues. This concept of joint function and lubrication is being tested at the present time.

\section{Summary}

Synovial fluid has been shown to be an effective lubricant for the synovium membrane if it contains hyaluronic acid with an intrinsic viscosity of about $4,000 \mathrm{ml} / \mathrm{g}$ or higher, and a concentration of greater than $0.5 \mathrm{ml} / \mathrm{g}$. Higher concentrations of hyaluronic acid with low viscosity values, however, were still able, in part, to serve as lubricants. Analysis and lubrication tests performed on synovial fluid from patients with rheumatoid arthritis showed that the lowest hyaluronic acid concentration was $0.8 \mathrm{mg} / \mathrm{ml}$ and the lowest intrinsic viscosity observed was 3,750 $\mathrm{ml} / \mathrm{g}$. All of the fluids, however, were able to lubricate synovial membrane in a similar manner to normal bovine synovial fluid. It seems unlikely, therefore, that the lubrication of soft tissue in joints would be a limiting function in patients with this disease.

The data obtained also confirm the earlier studies in that they showed the moiety responsible for articular lubrication was present in the protein fraction of synovial fluid and further indicate that the lubricating ability of this moiety does not depend upon the presence of hyaluronic acid or the interaction between these two constituents. As an explanation of these findings, it is suggested that articular lubrication may be an inherent property of the articular cartilage and its macromolecular structure per se, and that a component of the articular lubricating fraction isolated from synovial fluid may occur there as a consequence of wear processes.

This work was supported by research funds from the National Institutes of Health, Grant AM 15216 and the Shriners Burns Institute.

\section{References}

Atkins, E. D. T., And Sheehan, J. K. (1972) Nature (New Biol.), 235, 253 (Structure for hyaluronic acid) (1973) Science, 179, 562 (Hyaluronates: relation between molecular conformations)

Balazs, E. A., Berntsen, K. O., Karossa, J., And Swann, D. A. (1965) Anal. Biochem., 12, 547 (An automated method for the determination of hexuronic acids)

- Watson, D., Duff, I. F., AND Roseman, S. (1967) Arthr. and Rheum., 10, 357 (Hyaluronic acid in synovial fluid. 1. Molecular parameters of hyaluronic acid in normal and arthritic human fluids)

Barnett, C. H., Davies, D. V., ANd MacConaill, M. D. (1961) In 'Synovial Joints-Their Structure and Mechanics'. Thomas, Springfield, Illinois

Blau, S., Janis, R., Hamerman, D., and Sandson, J. (1965) Science, 150, 353 (Cellular origin of hyaluronateprotein in the human synovial membrane) 
Dea, I. C. M., Moorhouse, R., Rees, D. A., Arnott, S., Guss, J. M., And Balazs, E. A. (1973) Ibid., 179, 560 (Hyaluronic acid. A novel double helical molecule)

GregORY, J. D. (1973) Biochem. J., 133, 383 (Multiple aggregation factors in cartilage proteoglycan)

HaRdingham, T. E., AND MuIR, H. (1972) Biochim. biophys. Acta, 279, 401 (The specific interaction of hyaluronic acid with cartilage proteoglycans)

Hollander, J. L., AND MCCarTY, D. J. (eds.) (1972) In 'Arthritis and Allied Conditions', 8th ed. Lea and Febinger, Philadelphia; Kimpton, London

Laurent, T. C., Ryan, M., And Pietruszkiewicz, A. (1960) Biochim. biophys. Acta, 42, 476 (Fractionation of hyaluronic acid. The polydispersity of hyaluronic acid from the bovine vitreous body)

LinN, F. C. (1967) J. Bone Jt. Surg., 49A, 1079 (Lubrication of animal joints. I. The arthrotripsometer)

- (1968) J. Biomech., 1, 193 (Lubrication of animal joints. II. The mechanism)

Lowry, O. H., Rosebrough, N. J., Farr, A. L., and Randall, R. J. (1951) J. biol. Chem., 193, 265 (Protein measurement with the folin phenol reagent)

Radin, E. L., ANd Paul, I. L. (1972) J. Bone Jt. Surg., 54A, 607 (A consolidated concept of joint lubrication)

,-- Swann, D. A., AND Schottstaedt, E. S. (1971) Ann. rheum. Dis., 30, 322 (Lubrication of synovial membrane)

- Swann, D. A., AND WeIsSer, P. A. (1970) Nature, 228, 377 (Separation of a hyaluronate-free lubricating fraction from synovial fluid)

SCHER, I., AND HAMERMAN, D. (1972) Biochem. J., 126, 1073 (Isolation of human synovial-fluid hyaluronate by density-gradient ultracentrifugation and evaluation of its protein content)

Silpananta, P., Dunstone, J. R., And Ogston, A. G. (1968) Ibid., 109, 43 (Fractionation of a hyaluronic acid preparation in a density gradient. Some properties of the hyaluronic acid)

Swann, D. A. (1968a) Biochim. biophys. Acta, 156, 17 (Studies on hyaluronic acid. I. The preparation and properties of rooster comb hyaluronic acid)

(1968b) Ibid., 160, 96 (Studies on hyaluronic acid. II. The protein component(s) of rooster comb hyaluronic acid)

- (1969a) Biochem. biophys. Res. Commun., 35, 571 (Hyaluronic acid: structure of the macromolecule in the connective tissue matrix)

- (1969b) Biochem. J., 114, 819 (Studies on the structure of hyaluronic acid. Characterization of the product formed when hyaluronic acid is treated with ascorbic acid)

- (1970) 'On the state of hyaluronic acid in a connective tissue matrix,' in 'The Chemistry and Molecular Biology of the Intercellular Matrix', Vol. 2. Glycosaminoglycans and Proteoglycans, ed. E. A. Balazs, p. 743. Academic Press, New York.

- ANd Balazs, E. A. (1966) Biochim. biophys. Acta, 130, 112 (Determination of the hexosamine content of macromolecules with manual and automated techniques using the $p$-dimethylaminobenzaldehyde reaction)

- AND CONSTABLE, I. J. (1972) Invest. Ophthal., 11, 159 (Vitreous structure. I. Distribution of hyaluronate and protein)

-, AND RAdin, E. L. (1972) J. biol. Chem., 247, 8069 (The molecular basis of articular lubrication. I. Purification and properties of a lubricating fraction from bovine synovial fluid)

VARGA, L. (1955) Ibid., 217, 651 (Studies on hyaluronic acid prepared from the vitreous body) 